\title{
Bio-inventory of Spiders Located Inside the Maneknath Caves of Banaskantha, Gujarat, India
}

\section{Bhavesh M. Parmar}

Central Laboratory, Dudheswar waterworks, Amdavad Municipal Corporation, Ahmedabad -380004, Gujarat, India.

Study Area: Maneknath Caves, Danta Taluka, North Gujarat, India

Coordinates: $\cdot 24^{\circ} \mathrm{O} 7^{\prime} \mathrm{O} 1^{\prime \prime} \mathrm{N} ; 72^{\circ} 52^{\prime} 57^{\prime \prime} \mathrm{E}$

Key words: Archinida, Cave biodiversity.

\section{Abstract}

Spider bio inventory from five numbers of caves of Maneknath, of Gujarat was studied from 2016 to 2018. A total of 1332 Spider samples were collected using the Handpicking method. Out of 1332 samples, a total of 59 species and 48 genera from 22 families of spiders were identified. Araneidae was a diverse family with 11 species. Maneknath caves represented a total of $36.06 \%$ of the total families recorded earlier in India. This is the first documentation of the cave-dwelling spiders from the studyarea.

\section{Materials and methods:}

The cave is an exclusive environment with a quite stable climatic condition. This environment is characterized through the absence of light, high humidity, almost steady temperature, excessive $\mathrm{CO}_{2}$, and frequently restricted food resources (Vandel., 1965; Biswas, 2009; White et al., 2019). This extreme environmental circumstance turns into a selective force for many lives so that only particular species can stay and succeed in the traditional cave environment (Howarth, 2009; Romero, 2009; White et al., 2019). Arthropods are the most diverse and dominant assemblage of animals dwelling in a cave ecosystem, not solely in terms of species richness however, also in its roles in the ecosystem (Romero, 2009). Arthropods can act as predators, decomposers, and additionally food sources for various cave organisms (Vandel et al., 1965). Arthropods play important roles in preserving cave ecosystem stability (Rahmadi, 2002). Disruption of the Arthropod community in the cave ecosystem can disrupt different organisms' existence or destroying the whole cave ecosystem.

Spiders are common residents of caves (Howarth, 2003) with an extensive range of physiological and morphological adaptation. Naturally, spiders are usually well represented in caves given their exaptations to subterranean existence including, for most families, low dependence on vision and low metabolism allowing them to survive months except feeding (Foelix, 2011). There are more than a thousand species of troglobiont spiders and at least an equal number of troglophile spiders belonging to forty-eight families out of 47 ooo described species of spiders in 113 families (Mammola et al., 2017). This survey aimed to provide data on the bio-inventory of spiders within the Maneknath Caves.
The Survey and documentation were conducted from the period of 2016 to 2018 at different sites from Maneknath Caves. Maneknath Caves (Table-1) were located in Danta taluka, North Gujarat. In General, The cave was separated into three communities, determined based on cave zones: entrance, twilight and dark zones (White et al., 2019), as per cavian habitats, cavern, tops, holes, cracks, under a stone, debris, and grounds of the entrance, twilight, and dark zones of the caves were examined. Samples collection was made using the handpicking method. Spiders were collected in plastic bottles and later transferred in $70 \%$ ethyl alcohol-filled airtight vials for preservation purposes. All captured spiders were identified based on morphological characters to the lowest possible taxon level using relevant literature (Tikader, 1977; Tikader, 1987; Patel, 1972; Parmar, 2018; Gajbe, 2007; Sebastian et al., 2009; WSC, 2020). The data were analyzed by calculating indices and cluster analyses using the PAST (Paleontological Statistics Software).

\begin{tabular}{|c|c|c|}
\hline No & Sites name & Geographical location \\
\hline 1. & Main Cave & $24^{\circ} \mathrm{o6} 5^{\prime} 8^{\prime \prime} \mathrm{N} ; 72^{\circ} 52^{\prime} 59^{\prime \prime} \mathrm{E}$ \\
\hline 2. & Cave-I & $24^{\circ} \mathrm{o} 6{ }^{\prime} 52^{\prime \prime} \mathrm{N} ; 72^{\circ} 52^{\prime} 58^{\prime \prime} \mathrm{E}$ \\
\hline 3. & Cave-II & $24^{\circ} \mathrm{o6}{ }^{\prime} 1^{\prime \prime} \mathrm{N} ; 72^{\circ} 53^{\prime} \mathrm{O} 5^{\prime \prime} \mathrm{E}$ \\
\hline 4. & Cave-III & $24^{\circ} \mathrm{o} 6{ }^{\prime} 49^{\prime \prime} \mathrm{N} ; 72^{\circ} 53^{\prime} \mathrm{O} 3^{\prime \prime} \mathrm{E}$ \\
\hline 5. & Cave-IV & $24^{\circ} \mathrm{o} 6^{\prime} 45^{\prime \prime} \mathrm{N} ; 72^{\circ} 53^{\prime} \mathrm{O} 2^{\prime \prime} \mathrm{E}$ \\
\hline
\end{tabular}

Out of a total of 1332 individuals from order- Araneae distributed among 22 Families a total of 48 genera which included 59 species were collected during this study. Those organisms are generally found in caves, but also found in some other habitats are considered as troglophiles (Vandel,
Table-1: Geographical locations (Caves of Maneknath)

\section{Results \& Discussion:}

*Corresponding Author: parmarbhaveshkumar@gmail.com 
Table -2: Spiders collected from Various Caves

\begin{tabular}{|c|c|c|c|c|c|c|}
\hline \# Family & Genus/Species & M & I I & II & III & IV \\
\hline 1. ARANEIDAE & Araneus sp. & $\mathrm{A} 1$ & A $\mathrm{F}$ & $\mathrm{P}$ & $\mathrm{P}$ & $\mathrm{P}$ \\
\hline 2. & Argiope anasuja & A 1 & $\mathrm{P} \quad \mathrm{F}$ & $P$ & $\mathrm{P}$ & $\mathrm{P}$ \\
\hline 3. & Cyclosa bifida & A 1 & $\mathrm{P} \quad \mathrm{F}$ & $\mathrm{P}$ & $\mathrm{P}$ & $\mathrm{P}$ \\
\hline 4. & Cyrtophora cicatrosa & A 1 & $\mathrm{P} \quad \mathrm{F}$ & $\mathrm{P}$ & $\mathrm{P}$ & $\mathrm{P}$ \\
\hline 5. & Eriovixia excelsa & A 1 & A $\mathrm{F}$ & $\mathrm{P}$ & $\mathrm{P}$ & $\mathrm{P}$ \\
\hline 6. & Neoscona mukerjei & $\mathrm{P}$ & $\mathrm{P} \quad \mathrm{F}$ & $\mathrm{P}$ & $\mathrm{P}$ & $\mathrm{P}$ \\
\hline 7. & Neoscona nautica & A 1 & $\mathrm{P} \quad \mathrm{F}$ & $\mathrm{P}$ & A & $\mathrm{P}$ \\
\hline 8. & Neoscona odites & A 1 & A $\mathrm{F}$ & $\mathrm{P}$ & A & $\mathrm{P}$ \\
\hline 9. & Neoscona theisi & $\mathrm{P}$ & $\mathrm{P} \quad \mathrm{F}$ & $\mathrm{P}$ & $\mathrm{P}$ & $\mathrm{P}$ \\
\hline 10. & Neoscona sp. & $\mathrm{A}$ & A $A$ & A & $\mathrm{P}$ & $\mathrm{P}$ \\
\hline 11. & Poltys bhavnagarensis & $\mathrm{A}$ & $\mathrm{P} \quad \mathrm{F}$ & $\mathrm{P}$ & A & $\mathrm{A}$ \\
\hline 12. CLUBIONIDAE & Clubiona drassodes & A 1 & $\mathrm{P} \quad \mathrm{F}$ & $\mathrm{P}$ & $\mathrm{P}$ & $\mathrm{P}$ \\
\hline 13. & Clubiona sp. & $\mathrm{P}$ & A $\mathrm{F}$ & $\mathrm{P}$ & A & A \\
\hline 14. CORINNIDAE & Castianeira tinae & A 1 & $\mathrm{P} \quad A$ & A & $\mathrm{P}$ & A \\
\hline 15. & Castianei razetes & A 1 & $\mathrm{P} \quad \mathrm{F}$ & $\mathrm{P}$ & $\mathrm{P}$ & A \\
\hline 16. CTENIDAE & Ctinus sp. & $\mathrm{P}$ & $\mathrm{P} \quad A$ & A & A & A \\
\hline 17. ERESIDAE & Stegodyphus pacificus & $\mathrm{A}$ & $\mathrm{P} \quad \mathrm{F}$ & $\mathrm{P}$ & A & A \\
\hline 18. EUTICHURIDAE & Cheiracanthium sp. & A 1 & $\mathrm{P} \quad A$ & A & A & A \\
\hline 19. FILISTATIDAE & Filistate sp. & $\mathrm{P}$ & A $A$ & A & A & A \\
\hline 20. & Pritha sp. & $\mathrm{P}$ & A $\mathrm{F}$ & $\mathrm{P}$ & A & A \\
\hline 21. GNAPHOSIDAE & Drassodes sp. & $\mathrm{A}$ & A $\mathrm{F}$ & $\mathrm{P}$ & $\mathrm{P}$ & $\mathrm{P}$ \\
\hline 22. & Gnaphosa stoliczkai & A 1 & $\mathrm{P} \quad A$ & A & $\mathrm{P}$ & A \\
\hline 23. & Zelotes sp. & A 1 & $\mathrm{P} \quad A$ & A & $\mathrm{P}$ & A \\
\hline 24. HERSILIIDAE & Hersilia savignyi & $\mathrm{P}$ & $\mathrm{P} \mathrm{F}$ & $\mathrm{P}$ & $\mathrm{P}$ & $\mathrm{P}$ \\
\hline 25. LYCOSIDAE & Hippasa agelenoides & A 1 & $\mathrm{P} \quad \mathrm{F}$ & $\mathrm{P}$ & A & A \\
\hline 26. & Lycosa tista & A 1 & $\mathrm{P} \quad \mathrm{F}$ & $\mathrm{P}$ & A & A \\
\hline 27. & Lycosa sp. & A 1 & $\mathrm{P} \quad \mathrm{F}$ & $\mathrm{P}$ & $\mathrm{P}$ & $\mathrm{P}$ \\
\hline 28 . & Pardosa birmanica & A 1 & $\mathrm{P} \quad \mathrm{F}$ & $\mathrm{P}$ & $\mathrm{P}$ & A \\
\hline 29. OECOBIIDAE & Oecobius sp. & $\mathrm{P}$ & A $A$ & A & A & A \\
\hline 30. & Uroctea manni & $\mathrm{P}$ & A $A$ & A & A & A \\
\hline 31. & Uroctea indica & $\mathrm{P}$ & A $A$ & A & A & A \\
\hline 32. PHILODROMIDAE & Philodromus sp. & $\mathrm{P}$ & A $A$ & A & A & A \\
\hline 33. PHOLCIDAE & Physocyclus globosus & $\mathrm{P}$ & A $A$ & A & A & A \\
\hline 34. & Crossopriza lyoni & $\mathrm{P}$ & $\mathrm{P} \quad \mathrm{F}$ & $\mathrm{P}$ & $\mathrm{P}$ & $\mathrm{P}$ \\
\hline 35. & Pholcus phalangioides & $\mathrm{P}$ & $\mathrm{P} \quad \mathrm{F}$ & $\mathrm{P}$ & $\mathrm{P}$ & $\mathrm{P}$ \\
\hline 36. PSECHRIDAE & Psechrus sp. & $\mathrm{P}$ & A $A$ & A & A & A \\
\hline 37. SALTICIDAE & Carrhotus viduus & $\mathrm{P}$ & A $A$ & A & A & A \\
\hline 38. & Hasarius adansoni & $\mathrm{P}$ & A $A$ & A & A & A \\
\hline 39. & Menemerus bivittatus & $\mathrm{P}$ & $\mathrm{P} \mathrm{F}$ & $\mathrm{P}$ & $\mathrm{P}$ & A \\
\hline 40. & Menemerus fulvus & $\mathrm{P}$ & $\mathrm{P} \quad \mathrm{F}$ & $\mathrm{P}$ & $\mathrm{P}$ & A \\
\hline 41. & Phintella vittata & $\mathrm{P}$ & $\mathrm{P} A$ & A & A & A \\
\hline 42. & Plexippus paykulli & $\mathrm{P}$ & $\mathrm{P} \quad \mathrm{F}$ & $\mathrm{P}$ & A & A \\
\hline 43. SCYTODIDAE & Scytodes thoracica & $\mathrm{P}$ & A $A$ & A & A & A \\
\hline 44. SELENOPIDAE & Selenops sp. & A 1 & $\mathrm{P} \quad \mathrm{F}$ & $\mathrm{P}$ & $\mathrm{P}$ & $\mathrm{P}$ \\
\hline 45. SPARASSIDAE & Heteropoda venatoria & $\mathrm{P}$ & $\mathrm{P} \quad \mathrm{F}$ & $\mathrm{P}$ & $\mathrm{P}$ & $\mathrm{P}$ \\
\hline 46. & Heteropoda sp. & $\mathrm{P}$ & $\mathrm{P} \quad \mathrm{F}$ & $\mathrm{P}$ & $\mathrm{P}$ & $\mathrm{P}$ \\
\hline 47. SICARIIDAE & Loxosceles rufescens & $\mathrm{P}$ & $\mathrm{P} \quad \mathrm{F}$ & $\mathrm{P}$ & $\mathrm{P}$ & A \\
\hline 48. TETRAGNATHIDAE & Meta sp. & $\mathrm{P}$ & $\mathrm{P} \quad \mathrm{F}$ & $\mathrm{P}$ & $\mathrm{P}$ & A \\
\hline 49. & Tetragnatham axillosa & $a \mathrm{P}$ & A $A$ & A & A & A \\
\hline 50. & Tylorida ventralis & A 1 & $\mathrm{P} \quad A$ & A & A & A \\
\hline \multirow[t]{2}{*}{ 51. THERIDIIDAE } & Achaearanea triangula & aris & & & & \\
\hline & & A 1 & $\mathrm{P} \quad \mathrm{F}$ & $\mathrm{P}$ & $\mathrm{P}$ & $\mathrm{P}$ \\
\hline \multirow{2}{*}{52.} & Achaearaneate pidario & prum & & & & \\
\hline & & A 1 & $\mathrm{P} \quad \mathrm{F}$ & $\mathrm{P}$ & $\mathrm{P}$ & $\mathrm{P}$ \\
\hline 53. & Argyrodesar gentatus & A 1 & $\mathrm{P} \quad \mathrm{F}$ & $\mathrm{P}$ & A & A \\
\hline 54 . & Argyrodes flavescens & A 1 & $\mathrm{P} \quad \mathrm{F}$ & $\mathrm{P}$ & $\mathrm{P}$ & A \\
\hline 55. & Chrysso angula & A 1 & $\mathrm{P} \quad \mathrm{F}$ & $\mathrm{P}$ & A & A \\
\hline 56. & Steatoda grossa & A 1 & $\mathrm{P} \quad A$ & A & A & A \\
\hline
\end{tabular}

\begin{tabular}{lllllll} 
57. & Theridion sp. & A & A & A & A & A \\
58. ULOBORIDAE & Uloborus krishnae & P & P & A & A & A \\
59. & Uloborus plumipes & P & P & A & A & A \\
Total & & $\mathbf{2 9}$ & $\mathbf{4 0}$ & $\mathbf{3 6}$ & $\mathbf{2 9}$ & $\mathbf{2 1}$ \\
\hline
\end{tabular}

Table -3: Diversity Indices

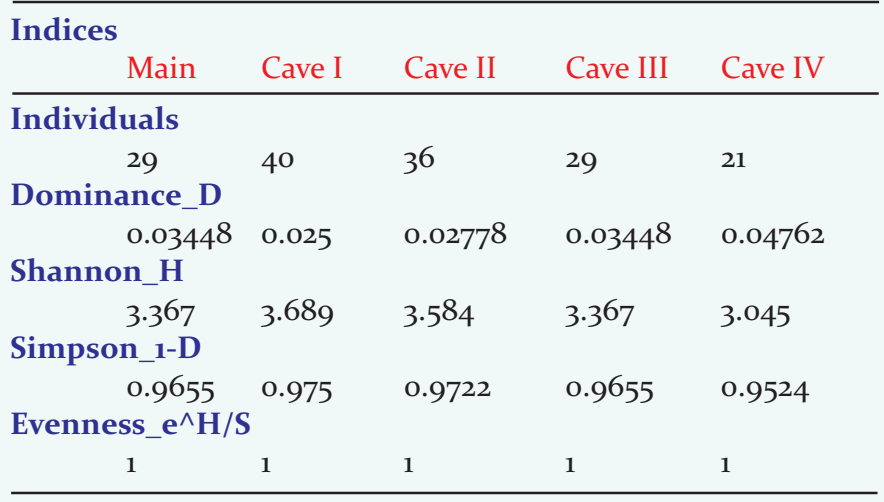

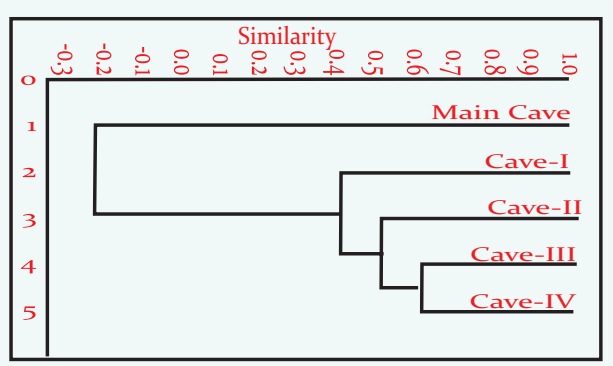

Figure-1: A dendrogram showing similarities between caves

1965). The list of spider's taxa is showing in Table-2.

Cave-I had the maximum number of species(40), Cave-II had 36 species followed by Cave-III (29), Main Cave (29), and Cave-IV (21). This indicates that Maneknath Caves supports a high diversity of organisms including spiders representing different trophic levels (Shetty et al. 2013). Cave-I and Cave-II had a Maximum number of spiders, because of this caves were absent of anthropogenic activities. Caves-III, Main Cave, and Cave-IV had the minimum number of spiders, due to having maximum human disturbance. The anthropogenic activity could negatively disturb some spiders while others are more tolerant of changes (Maya-Morales et al., 2012). It seems that Maneknath Caves acting a very significant role in the food web of the cave ecosystem, because, deprived of it, biotic components will not survive. The existence of groups of organisms in caves is actually dependent on the Caves micro-environment (Ferreira et al., 1999).

The diversity indices, Dominance_D, Simpson_1-D, Shannon_H, and Evenness_e $\mathrm{e}^{\wedge} \mathrm{H} / \mathrm{S}$ were determined using PAST: (Paleontological statistics software) for each site (Table-3). The value D will increase with decreasing diversity. Thus, Simpson's index is commonly suggested as its complement $1-\mathrm{D}$. Since $\mathrm{D}$ takes on values between zero and one and strategies one in the restriction of a monoculture, (1-D) offers an intuitive proportional measure of diversity that is much less sensitive to species 
richness. The diversity indices Shannon's index (J') and Simpson Diversity (D) are measures widely used as these indices to include each species richness and evenness to measure range the amount the quantity of abundant species in a sample and therefore the number of abundant species. Simpson index (D) that varied from zero to one given the likelihood that two individual species drawn at random from a population belong to the same species. Bray-Curtis's dissimilarity index was used for the formation of the dendrogram. The result of cluster analysis can be considered that the Cave-III community tended to be more similar to the Cave-IV community, whereas Main Cave tended to be different.This cluster analysis result potential that the community's similarity between Cave -III and Cave-IV was not only from the species composition aspect but also from the population of each species in these communities.

Finally, this was the first attempt to survey and observation of spider diversity in the cave ecosystem. The diversity both at the ecosystem and microhabitat level supports a huge amount of spiders in the Study Area. Changes in environmental circumstances due to mining, local tourism, and pilgrimage and tourism activities can threaten the survival of the spider communities inside it. Sustainable organizations of these caves should be applied to minimize the destructive impact of tourism on caves spider communities.

\section{References:}

Bento,D.D.M., Ferreira, R.L., Prous, X., Souza-Silva, M., Bellini, B.C. \& Vasconcellos, A.(2016): Seasonal variations in cave invertebrate communities in the Semiarid Caatinga, Brazil. L. Cave Karst Stud., 78(2):61-71.

Biswas, J. (2009): The biodiversity of Krem Mawkhyrdop of Meghalaya, India, on the verge of extinction. Current Sci., 96(7):904-910.

Foelix, R. (2011): Biology of Spiders, 3rd edition. Pub. by: Oxford University Press, UK. P. 432.

Ferreira, R.L. \& Martins, R.P. (1999): Trophic structure and natural history of bat guano invertebrate communities, with special reference to Brazilian caves. Trop. Zool., 12(2):231-252.

Gajbe, U.A. (2007): Araneae: Arachnida. Fauna of Madhya Pradesh (including Chhattisgarh), State Fauna Series. Zool. Surv. India, 15(1):419-540.

Hammer, Ø., Harper, D.A.T.\& Ryan, P.D. (2001): PAST: Palaeontological Statistics software packagefor education and data analysis. Palaeontol. Electron., 4(1):1-9.

Howarth, F.G. (2009): Encyclopedia of Insect: Cave Insect. 2nd ed. Pub. by: Elsevier, USA. P. 1168.
Howarth, F.G. (2003): Cave Insects, pp: 158-163. In, Resh V.H. \& Cardé R.T. (eds.): Encyclopedia of Insects. Pub. by: Elsevier Science. Academic Press. San Diego, California. USA.

Keswani, S., Hadole, P. \& Rajoria, A. (2012): Checklist of Spiders (Arachnida: Araneae) from India-2012. Indian J. Arachnol., 1(1):1-129.

Mammola, S. \& Isaia, M. (2017): Spiders in caves. Proc. Royal Soc. (Biol.Sci.), 284(1853):1-10.

Maya-Morales, J., Ibarra-Núñez, G., León-Cortés, J.L. \& Infante, F. (2012): Understory spider diversity in tworemnants of tropical montane cloud forest in Chiapas, Mexico. L. Insect Conserv., 16(1):25-38.

Palacios-Vargas, J.G., Castano-Meneses, G. \& Estrada, D.A. (2011): Diversity and dynamics of microarthropods from different biotopes of Las Sardinas Cave (Mexico). Subterranean Biol., 9:113-126.

Patel, B.H. (1972). Studies of spiders fauna (Araneae: Arachnida) from Gujarat. Ph.D. thesis, S. P. University, Anand. Gujrat, India.

Parmar, B.M. (2018): Some Spiders from in and around the Caves of Taranga Hills, Mahesana, Gujarat, India. Ambient Sci., 05(1):49-50.

Romero, A. (2009): Cave Biology, Life in Darkness. Pub. by: Cambridge University Press, UK.

Rahmadi, C. (2002). Keanekaragaman fauna Gua, Gua Ngerong, Tuban, JawaTimur: Tinjauan Khususpada Arthropoda. Zoo Indonesia J. Fauna Tropika, 29:19-27.

Shetty, S. \& Sreepada, K.S. (2013): Prey and nutritional analysis of Megaderma lyra guano from the West coast of Karnataka, India. Adv. Biores., 4(3):01-07.

Simoes, M.H., Souza-Silva, M. \& Ferreira, R.L.(2015): Cave physical attributes influencing the structure of terrestrial invertebrate communities in Neotropics. Subterranean Biol., 16:103-121.

Sebastian, P.A. \& Peter, K.V. (2009): Spiders of India, First edition, Pub. by: Universities Press, Hyderabad, India.

Tikader, B.K. (1977): Studies on spider fauna of Andaman and Nicobar islands, Indian Ocean. Rec. Zool. Sur. India,72:153212.

Tikader, B.K. (1987): Handbook of Indian Spiders. Pub. by: Zoological Survey of India. P. 251

White, W., Culver, D. \& Pipan, T. (2019): : Encyclopedia of Caves. 3rd edition. Pub. by: Elsevier, USA. P. 1250

WSC (2020): Natural History Museum Bern, online at http://wsc.nmbe.ch, version 18.5 .

Vandel, A. (1965): Biospeleology: the biology of cavernicolous animals . Pub. by: Pergamon Press, Oxford, PA. P. 524. 